\title{
Określenie możliwości odwadniania gazu ziemnego na membranach polimerowych
}

\begin{abstract}
Osuszanie gazu ziemnego na instalacjach glikolowych jest energochłonne i emituje do środowiska niebezpieczne związki chemiczne. Przeprowadzono badania osuszania azotu, metanu i gazu ziemnego na module membranowym. Badania wykonywano na mikrokapilarnych membranach (hollow fiber) z poliimidu. Moduł membranowy zamontowany był na stanowisku pomiarowym do badań w warunkach wysokiego ciśnienia gazu. Prowadzono pomiary przepływu strumieni gazu, ciśnienia, temperatury i wilgotności w strumieniach nadawy, retentatu i permeatu. Uzyskano wysokie stopnie obniżenia wilgotności w gazach. Stwierdzono, że efektywność osuszania gazu po kontakcie z membraną zależy od wartości przepływów i od ciśnienia. Wraz ze wzrostem ciśnienia transmembranowego efektywność odwodnienia się zwiększa. Przy ciśnieniu gazu powyżej 10 bar uzyskiwany jest poziom zawilgocenia odpowiadający wymaganiom normy osuszania gazu ziemnego w zimie, przy współczynniku podziału powyżej 0,08 . Przy ciśnieniu gazu powyżej 45 bar norma osuszania spełniona jest przy współczynniku podziału poniżej 0,01 . Wykazano, że technologia membranowa stanowi atrakcyjną metodę osuszania gazu ziemnego.
\end{abstract}

Słowa kluczowe: membranowa separacja gazowa, osuszanie gazu ziemnego.

\section{Possibility of natural gas dehydration using polymer membranes}

Dehydration of natural gas at glycol installations is energy-consuming and emits hazardous chemicals to the environment. Dehydration tests of nitrogen, methane and natural gas on a membrane module were conducted. The tests were conducted on micro-capillary membranes (hollow fiber) made of polyimide. The membrane module was mounted on a test station in high gas pressure conditions. The flow of the streams of gas, pressure, temperature and humidity in the streams of feed, retentate and permeate were conducted. High levels of humidity reduction in gases were obtained. It was found that the dehydration effectiveness of gas, after contact with the membrane, depends on the values of flows and pressure. With the increase of the transmembrane pressure, the effectiveness of dehydration increases. At a gas pressure above 10 bar, the level of humidity achieved is corresponding to the requirements of the standards for dehydration of natural gas in winter, with a partition coefficient (stage cut) above 0.08 . At a gas pressure above 45 bar, the standard for dehydration is met at a partition coefficient of less than 0.01 . It was proven that the membrane technology is an attractive method for natural gas dehydration.

Key words: membrane gas separation, natural gas dehydration.

\section{Wprowadzenie}

Wydobywany gaz ziemny zawiera parę wodną, najczęściej w stanie nasycenia. Jej obecność może powodować korozję rurociągów transportujących ten gaz lub powstawanie hydratów, dlatego istnieje potrzeba osuszania strumieni gazu ziemnego przed oddaniem go do sieci [5]. Normy wskazują dopuszczalną zawartość wilgoci w gazie wtłaczanym do linii przesyłowych - w okresie jesienno-zimowym przy ciśnieniu 5,5 MPa dopuszczalna zawartość wilgoci, wyrażona poprzez temperaturę punktu rosy, wynosi $-5^{\circ} \mathrm{C}$, zaś w okresie wiosenno-letnim jest równa $+3,7^{\circ} \mathrm{C}$.

Wartości dopuszczalnych temperatur punktu rosy odpowiadające zakresowi badanych ciśnień w tym artykule (według danych normy PN-C-04752:2011) przedstawiono na rysunku 1.

Wartościom wymaganych temperatur punktu rosy w przeliczeniu na zawartość wody w gazie odpowiada około $90 \mathrm{mg} / \mathrm{m}^{3}$ w okresie zimowym i około $145 \mathrm{mg} / \mathrm{m}^{3}$ w lecie. 


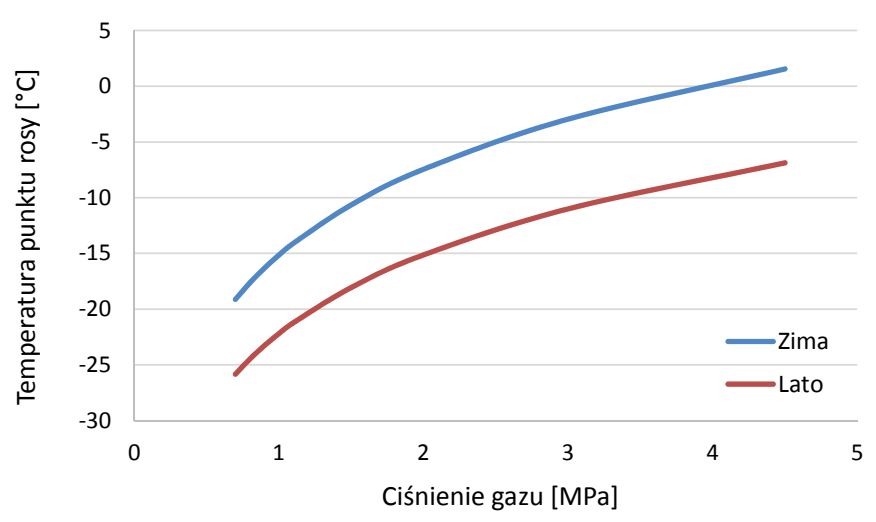

Rys. 1. Dopuszczalna temperatura punktu rosy w badanym zakresie ciśnień gazu ziemnego (według normy PN-C-04752:2011) [20]

Zawartość wody $\left(\mathrm{w} \mathrm{g} / \mathrm{m}^{3}\right)$ w gazie ziemnym w stanie nasycenia wodą $[3,11]$ przedstawiono poglądowo na rysunku 2 .

Jak wynika z wykresu, aby obniżyć zawartość wody w gazie nasyconym $\mathrm{w}$ temperaturze otoczenia do poziomu wymaganego w normie, należy usunąć z niego znacznie powyżej $90 \%$ wody.

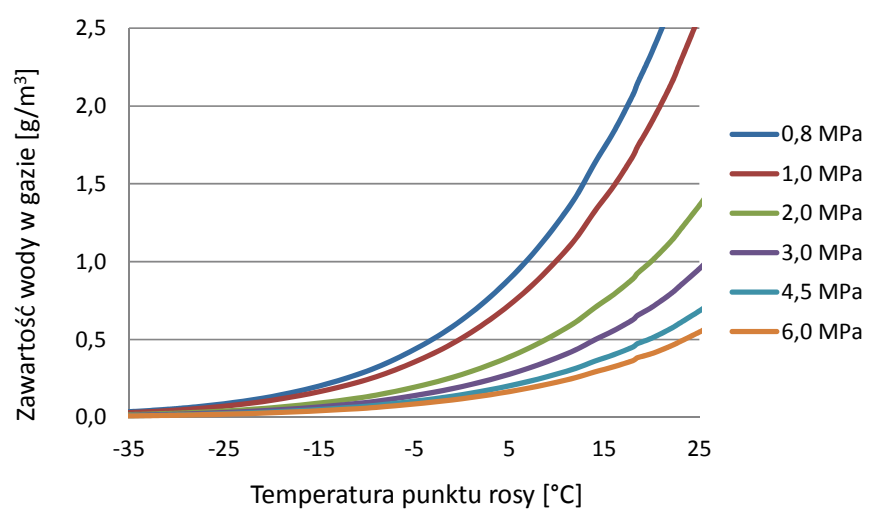

Rys. 2. Kształtowanie się stężenia nasyconej pary wodnej w gazie dla ciśnień: $0,8 \div 6 \mathrm{MPa}$ w zależności od temperatury punktu rosy. Wartości nasycenia wody gazem obliczano według formuły Bukaceka [3]

Do osuszania gazu ziemnego stosuje się wiele metod, do których należą: absorpcja (glikole), adsorpcja (sole chlorków wapnia, magnezu i litu oraz krzemionka i sita molekularne), wykorzystanie efektu Joule'a i Thompsona, a także techniki membranowe. W przypadku złóż o bardzo dużych zasobach gazu budowa dużej, choć kosztownej instalacji absorpcyjnej jest standardem. Inaczej jednak należy rozpatrywać obróbkę gazu pochodzącego ze złóż ubogich w gaz lub wydobywanego na platformach morskich. W takiej sytuacji na atrakcyjności zyskują techniki membranowe, z mobilnymi i modułowymi instalacjami. W przypadku większych złóż gazu ziemnego techniki membranowe przegrywają jeszcze w konkurencji z metodami tradycyjnymi. Absorpcja w glikolach pozwala na obniżenie zawar- tości wody w strumieniu gazu do 10 ppm i choć jest szeroko akceptowana w przemyśle, ma także pewne wady. Zaliczyć do nich można konieczność regeneracji dużych ilości sorbentu, podatność na pienienie się i utlenianie się glikolu. Glikole sorbują z surowego gazu także wiele lotnych związków organicznych, zwłaszcza benzen, toluen, etylobenzen i ksylen (BTEX), które podczas regeneracji dostają się do atmosfery, i stały się poważnym źródłem emisji. Na przykład, typowa jednostka na bazie glikolu odwadniająca strumień gazu ziemnego $1000 \mathrm{~m}^{3} / \mathrm{min}$ emituje rocznie ponad 40 ton różnych zanieczyszczeń organicznych, z których połowę stanowi BTEX $[8,9,10]$. Obecnie w samych tylko Stanach Zjednoczonych rocznie $\mathrm{z}$ wydobycia $700 \mathrm{mld} \mathrm{m}^{3}$ gazu ziemnego emisje zanieczyszczeń organicznych z glikolowych instalacji osuszania wynoszą szacunkowo 57000 ton. Do metod osuszania gazu ziemnego zalicza się też nowoczesne metody rozdziału, jakimi są techniki membranowe, które cieszą się coraz większym zainteresowaniem przemysłu wydobywczego i zaczynają powoli zdobywać uznanie. Do zalet takiego rozwiązania można zaliczyć śladową energochłonność i modularność technik membranowych, co pozwala na dopasowanie procesu do bieżących potrzeb przy stosunkowo niewielkim spadku ciśnienia osuszanego gazu [17]. Brak jest również w tej metodzie konieczności stosowania substancji pomocniczych, co czyni ją dodatkowo atrakcyjną, pozwalając na uzyskanie zawartości wody w strumieniu gazu na poziomie poniżej 100 ppm. Układy membranowe są zwarte, o małych rozmiarach, pasywne, bez ruchomych części i niezawodne - nie wymagają ciągłej uwagi podczas pracy w oddalonych miejscach. W tych procesach emisja VOC (lotnych związków organicznych) może być zupełnie wyeliminowana. Procesy membranowe mogą być bardziej konkurencyjne cenowo w porównaniu do technologii absorpcji i adsorpcji. Osuszanie gazów z użyciem technik membranowych wykorzystywane jest w przemyśle chemicznym, gazownictwie, przy produkcji biogazu oraz do zagospodarowania spalin $[1,2,14,15]$. W przemyśle naftowym zastosowanie membran wiąże się z możliwością korekty składu gazu dla potrzeb systemu gazowniczego $[7,17]$ lub lokalnego wykorzystania gazu.

Przełomem w zastosowaniu membran w procesie osuszania było zastąpienie dotychczas używanych membran ze zwykłego octanu celulozy jej modyfikowanymi odmianami, a także polimerami na bazie aromatów (PI, PA) oraz membranami kondycjonowanymi hydrofilowymi domieszkami. Duży wpływ na wdrażanie w światowym przemyśle naftowym membranowej metody osuszania mają także procesowe rozwiązania technologiczne, które uczyniły ten proces bardziej opłacalnym [1, 14-17, 19]. Mimo wymienionych 
powyżej zalet układy membranowe są wykorzystywane tylko do zastosowań niszowych. Niniejszy artykuł wpisuje się wraz z innymi obecnie prowadzonymi na świecie badania- mi w proces określenia technicznego uzasadnienia wdrożenia technologii membranowej do odwadniania gazu ziemnego $[2,4,6,16]$.

\section{Separacja membranowa}

Separacja membranowa par i gazów to dwuetapowy proces sorpcji i dyfuzji [1]. Molekuły gazu adsorbowane są na powierzchni membrany, a następnie dyfundują w poprzek przegrody, ulegając desorpcji po drugiej (niskociśnieniowej) stronie membrany, tworząc tzw. permeat. Strumień wlotowy gazu (nadawa) po kontakcie z membraną zubożony jest o składniki przechodzące przez membranę (np. parę wodną); na wylocie określany jest jako retentat. Separacja składników gazu jest możliwa dzięki temu, że posiadają one różne współczynniki permeacji $P$ (przepuszczalności). Jednostką przepuszczalności $(P)$ powszechnie stosowaną w publikacjach związanych z separacją membranową jest barrer $\left(1\right.$ barrer $\left.=10^{-10} \mathrm{~cm}^{3}(\mathrm{STP}) \times \mathrm{cm} / \mathrm{cm}^{2} \times \mathrm{s} \times \mathrm{cm} \mathrm{Hg}\right)$ [17] Stosunek przepuszczalności dwóch gazów A i B nazywany jest selektywnością $\alpha_{A / B}$ (lub współczynnikiem separacji):

$$
\alpha_{A / B}=P_{A} / P_{B}
$$

Na rzeczywisty rozdział składników mają też wpływ makroskopowe czynniki związane z konstrukcją modułów membranowych, takie jak czas kontaktu gazu po stronie wysokociśnieniowej z powierzchnią membrany. Strumień wpływającego do modułu gazu (nadawy) $-F$ zmniejsza się o strumień przechodzący przez membranę (permeatu) $-N$.

Stosunek objętości permeatu $(N)$ do objętości nadawy $(F)$ określamy jako współczynnik podziału $\theta$ (stage cut):

$$
\theta=N / F
$$

Współczynnik podziału może być częściowo sterowany w rzeczywistych procesach poprzez regulowanie szybkości przepływu gazu w części wysokociśnieniowej [2, 7, 17].

\section{Opis aparatury}

Badania zostały przeprowadzone na module z kapilarnymi membranami poliimidowymi. Ta zwarto-porowata membrana charakteryzuje się unikalną strukturą, wynikającą ze zmiennej porowatości w poprzecznym przekroju. Membrany te cechuje szczególnie duża odporność na działanie wysokich temperatur, zachowują trwałość kształtu nawet przy długotrwałych obciążeniach, w podwyższonych temperaturach - nie ulegają pełzaniu. Są odporne na pęcznienie ze strony typowych składników gazu ziemnego, mogących ulec chwilowej kondensacji. Membrany z polimerów poliimidowych cechują się wysoką jakością i trwałością [18]. Posiadany przez INiG - PIB moduł z tymi kapilarnymi membranami firmy UBE ma długość $35 \mathrm{~cm}$ i średnicę obudowy $28 \mathrm{~mm}$ (fotografia 1).

Moduł został wkomponowany w stanowisko badawcze do separacji gazów w sposób przedstawiony na rysunku 3.

Moduł membranowy stanowił główną część instalacji pomiarowej wyposażonej w nawilżacz gazu, wymiennik ciepła, zawory regulujące przepływy strumieni i ciśnienia, termometry oraz przepływomierze. Gaz do modułu wpływał do przestrzeni pomiędzy membrany kapilarne. Wlot nadawy umiejscowiony był po stronie odbioru strumienia permeatu. Szczelność instalacji badawczej sprawdzono dla ciśnienia $7 \mathrm{MPa}$. Całość wykonana została ze stali nierdzewnej.

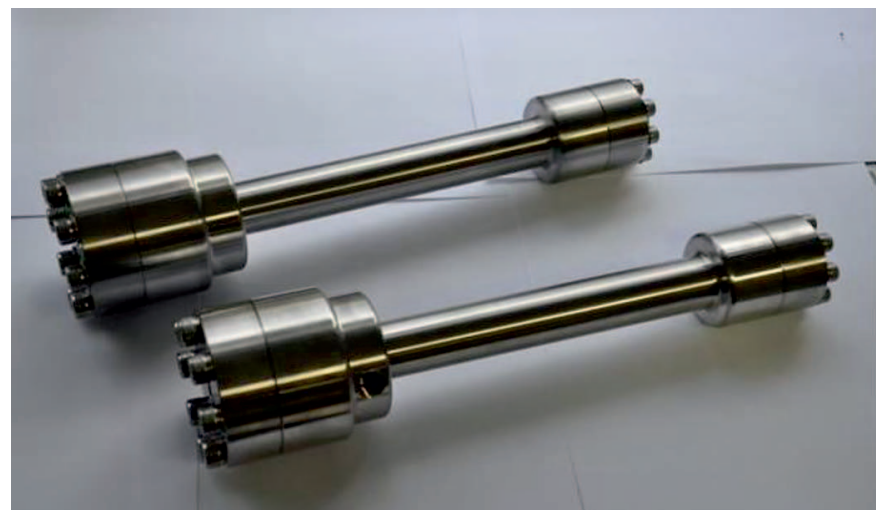

Fot. 1. Zdjęcie modułów membranowych w obudowie stalowej

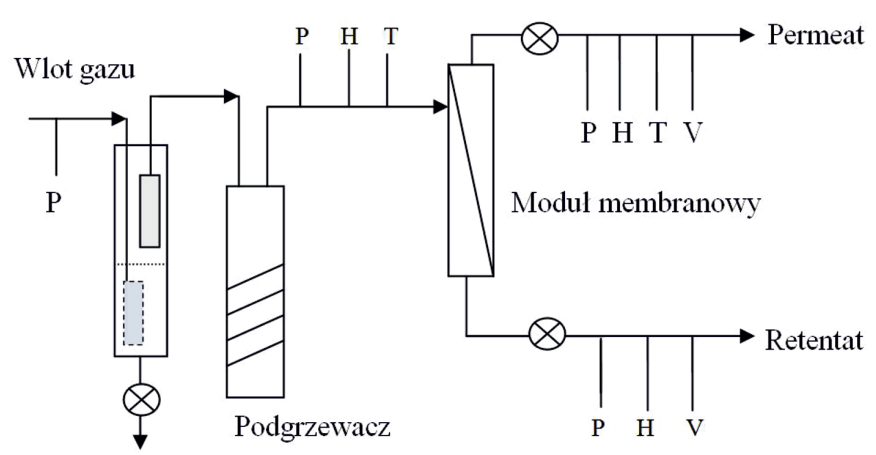

Nawilżacz

Rys. 3. Schemat laboratoryjnej instalacji do separacji gazów

(P, T, H i V - pomiar ciśnienia, temperatury, wilgotności i przepływu) 


\section{Opis metodyki pomiarowej}

Każdy składnik mieszaniny gazowej w gazie wlotowym w kontakcie z membraną wpływa na ogólną przepuszczalność i skład gazu za membraną. Im większa ilość tych składników, tym trudniej zaobserwować wpływ różnych zjawisk fizycznych na subtelne mechanizmy procesu permeacji gazu. Badania postanowiono prowadzić przy użyciu azotu, metanu i wysokometanowego gazu ziemnego z kopalni Rzeszów (nie stwierdzając różnicy w wartościach pomiarów przepływu permeatu $\mathrm{w}$ funkcji ciśnienia $\mathrm{z}$ metanem technicznym). Pomiary przepływów wykonywano za pomocą przepływomierza Alicat D.5M.MIX w zakresie do $10 \mathrm{l} / \mathrm{min}$, a w zakresie do $0,8 \mathrm{l} / \mathrm{min}$ sprawdzano przepływ przyrządem Agilent ADM 1000. Wszystkie wskazania przepływomierzy zostały skalibrowane na jednostki $\mathrm{ml} / \mathrm{min}$ dla $18,5^{\circ} \mathrm{C}$ i $982 \mathrm{kPa}$ (warunki prowadzenia pomiarów).

Badania punktu rosy wykonywane były za pomocą higrometru MMS-35IS firmy Panametrics (obecnie General Electric) przy użyciu sondy M2LR umieszczonej w strumieniu retentatu pod pełnym ciśnieniem gazu. Niepewność ozna- czenia przepływów oszacowano na podstawie klasy dokładności urządzenia pomiarowego D.5M.MIX (nie przekracza ona $0,5 \%$ ). Konstrukcja nawilżacza w badanych warunkach przepływu pozwalała na wystarczająco długi czas kontaktu gazu z wodą, aby gaz był w pełni nasycony w danym ciśnieniu. Niezależnie od tego co pewien czas wykonywano pomiar temperatury punktu rosy gazu za nawilżaczem (czy odpowiada $99,5 \div 100 \%$ wartości teoretycznej pełnego nasycenia dla ciśnienia gazu wlotowego).

$\mathrm{Z}$ tablic $[3,11]$ odczytywano masę wody odpowiadającą punktowi rosy w danych warunkach ciśnienia i temperatury w strumieniu wlotowym i retentacie (gaz osuszony). Wykonywano średnio trzy odczyty w odstępie kilku minut dla każdego ustalonego warunku pomiarowego. Badania rozpoczęto od określenia zależności wielkości strumienia permeatu od ciśnienia dla azotu i metanu. Górnym ograniczeniem wielkości ciśnienia w tych testach była możliwość utrzymywania w czasie stałego stabilnego przepływu na reduktorze butlowym oraz zakresy pomiarowe przepływomierzy.

\section{Wyniki pomiarów}

Celem uzyskania danych w szerokim zakresie ciśnień i eliminacji zakłóceń procesowych, a także ze względu na bezpieczeństwo - badania rozpoczęto od osuszania wilgotnego azotu. Pozwoliło to na odpowiednie ustawienie poziomu wody w nawilżaczu gazu, opanowanie precyzyjnego operowania zaworami w odpowiedniej kolejności, aby nie dopuścić do zalania instalacji, oraz na likwidację nieszczelności i bezpieczne odprowadzanie wykorzystanego gazu poza pomieszczenia laboratoryjne, przy użyciu wyodrębnionego ko- mina $\mathrm{z}$ wymuszoną wentylacją. $\mathrm{W}$ trakcie wszystkich badań odczytywano ciśnienie wlotowe gazu $\left(P_{\text {wlot }}\right)$, ciśnienie na wyjściu z modułu membranowego, przepływy permeatu, retentatu i temperaturę gazu oraz temperaturę punktu rosy retentatu.

Badania wykonywano przy stosunku przepływu strumienia permeatu do przepływu gazu wlotowego (stage cut) wynoszącym od $6 \%$ do $40 \%$ (współczynnik podziału od 0,06 do 0,4 ). Wyniki serii pomiarowej osuszania gazu (azotu) przy ciśnieniu 8 bar w module membranowym przedstawiono w tablicy 1 .

Tablica 1. Wyniki serii pomiarowej osuszania gazu (azotu) przy ciśnieniu 8 bar w module membranowym

\begin{tabular}{|c|c|c|c|c|c|c|c|c|c|}
\hline$P_{\text {wlot }}$ & $P_{\text {ret }}$ & $T_{\text {rosy }}$ & $V_{\text {perm }}$ & $V_{\text {wlot }}$ & $T_{\text {gazu }}$ & $M_{\text {wody }}$ wlot & $M_{\text {wody }}$ retentat & \multirow{2}{*}{$\begin{array}{c}\text { Współczynnik } \\
\text { podziału }\end{array}$} & \multirow{2}{*}{$\begin{array}{c}\text { Stopień } \\
\text { odwodnienia }\end{array}$} \\
\hline [bar] & [bar] & {$\left[{ }^{\circ} \mathrm{C}\right]$} & {$[\mathrm{ml} / \mathrm{min}]$} & {$[\mathrm{ml} / \mathrm{min}]$} & {$\left[{ }^{\circ} \mathrm{C}\right]$} & {$\left[\mathrm{mg} / \mathrm{m}^{3}\right]$} & {$\left[\mathrm{mg} / \mathrm{m}^{3}\right]$} & & \\
\hline 8,2 & 8 & $-20,6$ & 141 & 2350 & 18,5 & 2150 & 146 & 0,06 & 0,932 \\
\hline 8,2 & 8 & $-20,5$ & 139 & 2316 & 18,5 & 2150 & 151 & 0,06 & 0,930 \\
\hline 8,2 & 8 & $-20,7$ & 142 & 2366 & 18,5 & 2150 & 151 & 0,06 & 0,930 \\
\hline 8,1 & 8 & $-21,8$ & 142 & 1434 & 18,5 & 2150 & 115 & 0,10 & 0,947 \\
\hline 8,1 & 8 & $-21,8$ & 141 & 1444 & 18,5 & 2150 & 115 & 0,10 & 0,947 \\
\hline 8,1 & 8 & $-21,8$ & 140 & 1425 & 18,5 & 2150 & 115 & 0,10 & 0,947 \\
\hline 8,1 & 8 & $-22,5$ & 140 & 700 & 18,5 & 2150 & 108 & 0,20 & 0,950 \\
\hline 8,1 & 8 & $-22,5$ & 141 & 710 & 18,5 & 2150 & 108 & 0,20 & 0,950 \\
\hline 8,1 & 8 & $-22,5$ & 142 & 712 & 18,5 & 2150 & 108 & 0,20 & 0,950 \\
\hline 8,1 & 8 & $-22,8$ & 140 & 350 & 18,5 & 2150 & 98 & 0,40 & 0,954 \\
\hline 8,1 & 8 & $-22,8$ & 141 & 354 & 18,5 & 2150 & 98 & 0,40 & 0,954 \\
\hline 8,1 & 8 & $-22,8$ & 142 & 349 & 18,5 & 2150 & 98 & 0,41 & 0,954 \\
\hline
\end{tabular}


Tablica 2. Wyniki serii pomiarowej osuszania gazu (azotu) przy ciśnieniu 45 bar w module membranowym

\begin{tabular}{|c|c|c|c|c|c|c|c|c|c|}
\hline$P_{\text {wlot }}$ & $P_{\text {ret }}$ & $T_{\text {rosy }}$ & $V_{\text {perm }}$ & $V_{\text {wlot }}$ & $T_{\text {gazu }}$ & $M_{\text {wody }}$ wlot & $M_{\text {wody }}$ retentat & $\begin{array}{c}\text { Współczynnik } \\
\text { podziału }\end{array}$ & $\begin{array}{c}\text { Stopień } \\
\text { odwodnienia }\end{array}$ \\
\hline$[\mathrm{bar}]$ & {$[\mathrm{bar}]$} & {$\left[{ }^{\circ} \mathrm{C}\right]$} & {$[\mathrm{ml} / \mathrm{min}]$} & {$[\mathrm{ml} / \mathrm{min}]$} & {$\left[{ }^{\circ} \mathrm{C}\right]$} & {$\left[\mathrm{mg} / \mathrm{m}^{3}\right]$} & {$\left[\mathrm{mg} / \mathrm{m}^{3}\right]$} & 11,5 & 0,1 \\
\hline 45,1 & 45 & $-34,0$ & 793 & 8000 & 18,5 & 465 & 10,0 & 0,2 & 0,975 \\
\hline 45,1 & 45 & $-36,0$ & 793 & 4012 & 18,5 & 465 & 10,0 & 0,2 & 0,978 \\
\hline 45,1 & 45 & $-36,0$ & 793 & 3930 & 18,5 & 465 & 8,9 & 0,4 & 0,981 \\
\hline 45,1 & 45 & $-37,5$ & 799 & 1905 & 18,5 & 465 & 8,9 & 0,4 & 0,981 \\
\hline 45,1 & 45 & $-37,5$ & 793 & 2000 & 18,5 & 465 & 8,9 & 0,4 & 0,981 \\
\hline 45,1 & 45 & $-37,5$ & 788 & 1970 & 18,5 & 465 & 8,9 & \\
\hline
\end{tabular}

Jak wynika z tablicy 1, wraz ze zmniejszaniem się przepływu gazu wlotowego (wzrostem współczynnika podziału) temperatura punktu rosy ulega obniżeniu i rośnie stopień odwodnienia (stosunek masy wody w retentacie do masy wody zawartej w gazie wlotowym). W procesie osuszania gazu na membranach przy temperaturze gazu $18,5^{\circ} \mathrm{C}$, gdzie zawartość pary wodnej wynosi $2,15 \mathrm{~g} / \mathrm{m}^{3}$, uzyskujemy temperatury punktu rosy od $-20,5^{\circ} \mathrm{C}$ do $-22,8^{\circ} \mathrm{C}$, co odpowiada zawartości pary wodnej w granicach $0,1 \div 0,15 \mathrm{~g} / \mathrm{m}^{3}$, co z kolei odpowiada usunięciu wody z gazu na poziomie $93 \div 95 \%$.

Następnie badania efektów osuszania wilgotnego azotu w stanie nasycenia prowadzono w kolejno coraz wyższych ciśnieniach (15, 20, 30 i 45 bar). Wyniki serii pomiarowej dla ciśnienia 45 bar przedstawiono w tablicy 2 .

W tej serii pomiarowej (45 bar) nie udało się wykonać pomiarów dla współczynnika podziału 0,06 , ponieważ wartości przepływu azotu przekroczyły zakres pomiarowy stosowanych mierników. Jak wynika z tego zestawienia, współczynniki odwodnienia gazu wynoszą ponad 97\%. Na rysunku 4 przedstawiono rezultaty całej serii pomiarów temperatury punktu rosy strumienia azotu po kontakcie z membraną w zależności od współczynnika podziału przy ciśnieniach: 8, 15, 20, 30 i 45 bar. Na rysunku 5 zilustrowano kształtowanie się stopnia odwodnienia strumienia azotu po kontakcie z membraną w zależności od współczynnika podziału dla wszystkich serii pomiarowych - przy ciśnieniach: 8,15 , 20, 30 i 45 bar.

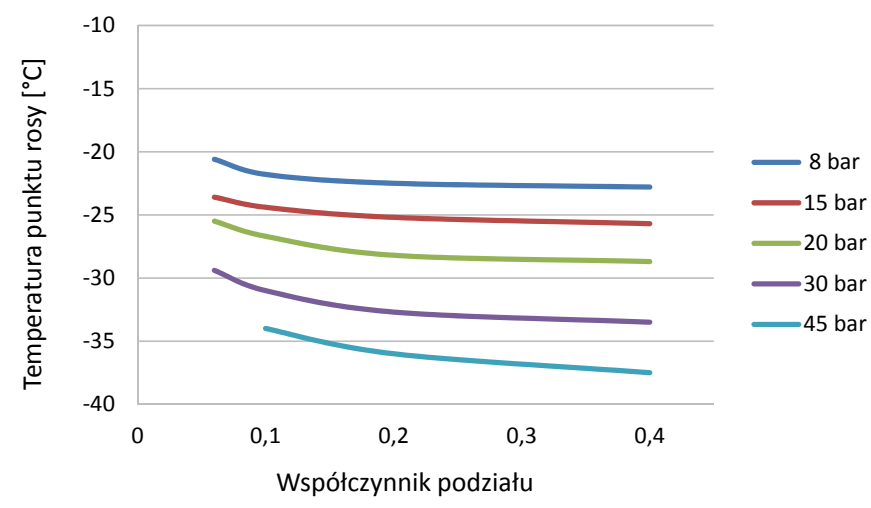

Rys. 4. Wyniki pomiarów temperatury punktu rosy strumienia azotu po kontakcie z membraną w zależności od współczynnika podziału przy ciśnieniach: 8, 15, 20, 30 i 45 bar

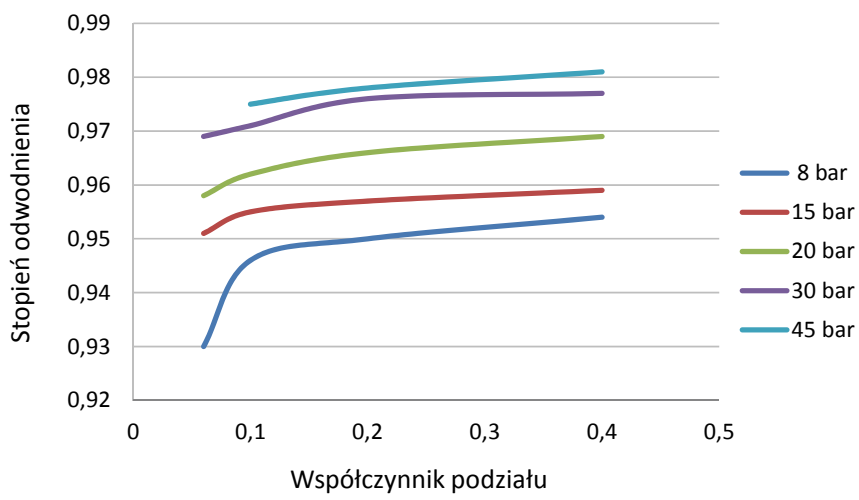

Rys. 5. Kształtowanie się stopnia odwodnienia strumienia azotu po kontakcie z membraną w zależności od współczynnika podziału przy ciśnieniach: $8,15,20,30$ i 45 bar

Tablica 3. Wyniki serii pomiarowej osuszania metanu przy ciśnieniu 45 bar w module membranowym

\begin{tabular}{|c|c|c|c|c|c|c|c|c|c|}
\hline$P_{\text {wlot }}$ & $P_{\text {ret }}$ & $T_{\text {rosy }}$ & $V_{\text {perm }}$ & $V_{\text {wlot }}$ & $T_{\text {gazu }}$ & $M_{\text {wody }}$ wlot & $M_{\text {wody }}$ retentat & \multirow{2}{*}{$\begin{array}{l}\text { Współczynnik } \\
\text { podziału }\end{array}$} & \multirow{2}{*}{$\begin{array}{c}\text { Stopień } \\
\text { odwodnienia }\end{array}$} \\
\hline [bar] & [bar] & {$\left[{ }^{\circ} \mathrm{C}\right]$} & {$[\mathrm{ml} / \mathrm{min}]$} & {$[\mathrm{ml} / \mathrm{min}]$} & {$\left[{ }^{\circ} \mathrm{C}\right]$} & {$\left[\mathrm{mg} / \mathrm{m}^{3}\right]$} & {$\left[\mathrm{mg} / \mathrm{m}^{3}\right]$} & & \\
\hline 45,1 & 45 & $-33,5$ & 516 & 8600 & 18,5 & 474 & 12,0 & 0,06 & 0,975 \\
\hline 45,1 & 45 & $-34,9$ & 516 & 5205 & 18,5 & 474 & 10,0 & 0,10 & 0,979 \\
\hline 45,1 & 45 & $-35,1$ & 516 & 5175 & 18,5 & 473 & 10,0 & 0,10 & 0,979 \\
\hline 45,1 & 45 & $-37,5$ & 517 & 2600 & 18,5 & 473 & 8,9 & 0,20 & 0,981 \\
\hline 45,1 & 45 & $-37,5$ & 516 & 2580 & 18,5 & 473 & 8,9 & 0,20 & 0,981 \\
\hline 45,1 & 45 & $-39,1$ & 515 & 1280 & 18,5 & 473 & 8,0 & 0,40 & 0,983 \\
\hline 45,1 & 45 & $-38,9$ & 516 & 1260 & 18,5 & 473 & 8,0 & 0,40 & 0,983 \\
\hline
\end{tabular}


Dalszą część badań prowadzono z użyciem metanu i gazu ziemnego wysokometanowego, który podobnie jak azot nasycany był wodą w nawilżaczu w warunkach pomiarowych. Metan nieco wolniej w stosunku do azotu przepływa przez membranę, dlatego dla ciśnienia gazu 45 bar wykonano oznaczenie zawilgocenia retentatu także dla współczynnika podziału 0,06, w związku z możliwością pomiarów przepływu retentatu, co przedstawiono w tablicy 3 .

Spośród wszystkich danych serii pomiarowych osuszania metanu na rysunku 6 przedstawiono kształtowanie się stopnia odwodnienia strumienia metanu po kontakcie z membraną w zależności od współczynnika podziału dla badanych ciśnień.

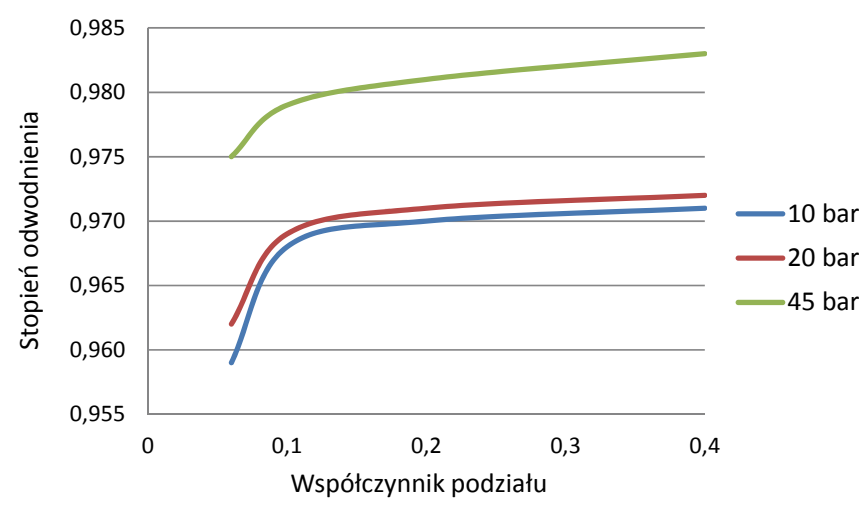

Rys. 6. Kształtowanie się stopnia odwodnienia strumieni metanu po kontakcie $\mathrm{z}$ membraną $\mathrm{w}$ zależności od współczynnika podziału przy ciśnieniach: 10, 20 i 45 bar

Na podstawie porównania rysunków 5 i 6 można stwierdzić, że stopień odwodnienia dla metanu jest nieco wyższy niż dla azotu, co związane jest z większym współczynnikiem permeacji azotu.

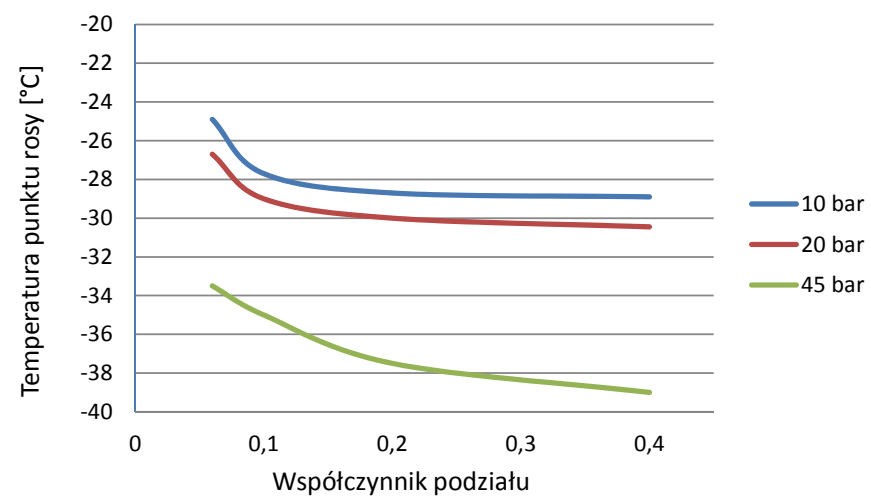

Rys. 7. Kształtowanie się temperatury punktu rosy strumienia metanu po kontakcie $\mathrm{z}$ membraną $\mathrm{W}$ zależności od współczynnika podziału przy ciśnieniach: 10, 20 i 45 bar

Jak wynika z przeprowadzonych badań osuszania gazu na module $\mathrm{z}$ membranami poliimidowymi, uzyskano wysokie stopnie odwodnienia metanu i azotu. Na rysunku 7 przedstawiono kształtowanie się temperatury punktu rosy strumie- nia metanu po kontakcie $\mathrm{z}$ membraną $\mathrm{w}$ temperaturze $18,5^{\circ} \mathrm{C}$ w zależności od współczynnika podziału.

Jak wynika $z$ laboratoryjnych badań odwadniania metanu i azotu na module $z$ kapilarnymi membranami poliimidowymi, istnieje realna możliwość zastosowania membran do procesu osuszania gazu ziemnego. Badany typ membran z polimerów szklistych jest doskonałym materiałem do tego przedsięwzięcia. Podczas wcześniejszych badań separacji składników gazu ziemnego na tej membranie [7] uzyskano kilkuprocentowe obniżenie zawartości azotu oraz kilkudziesięcioprocentowe zmniejszenie zawartości dwutlenku węgla w gazie ziemnym, co dodatkowo uatrakcyjnia ewentualne przemysłowe wdrożenie tej technologii. Proces może być prowadzony w szerokim zakresie warunków PVT bez konieczności ingerencji operatorów przy zmianie parametrów. Aby określić granicę zastosowania badanej techniki membranowej, przeanalizowane zostały wyniki wykonanych testów osuszania na podstawie masowej zawartości wody w metanie po kontakcie z membraną. Na rysunku 8 przedstawiono kształtowanie się zawartości wody w gazie osuszonym w funkcji współczynnika podziału.

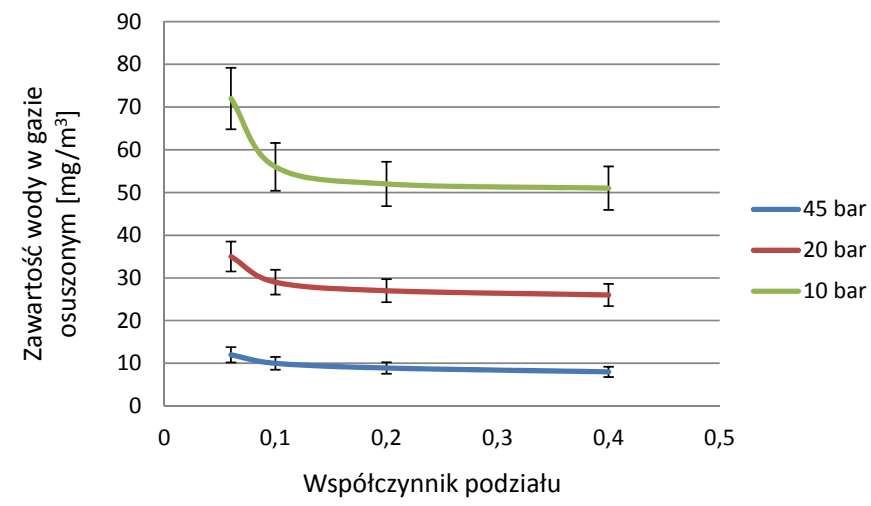

Rys. 8. Kształtowanie się zawartości wilgoci w strumieniu metanu po kontakcie $\mathrm{z}$ membraną $\mathrm{w}$ zależności od współczynnika podziału przy ciśnieniach: 10, 20 i 45 bar w temperaturze $18,5^{\circ} \mathrm{C}$

W prowadzonych badaniach ze względów technicznych ograniczono się do testów, w których najniższym współczynnikiem podziału strumieni jest 0,06 . W tym zakresie wszystkie uzyskane wyniki spełniają zarówno letnie, jak i zimowe normy zawartości wilgoci $\left(91 \mathrm{mg} / \mathrm{m}^{3}\right.$ w zimie i $145 \mathrm{mg} / \mathrm{m}^{3}$ w lecie). Jednak wielkość strumienia gazu niskociśnieniowego (mokrego permeatu) na poziomie 6\% może być nieakceptowalna przez inwestorów. W celu wykreowania spodziewanych wartości zawilgocenia przy niższych „stratach” metanu (dla współczynnika podziału $<0,06$ ) przeprowadzono interpolację wyników z wykorzystaniem potęgowej linii trendu, co przedstawiono na rysunku 9.

Liniami kropkowanymi zaznaczono linie trendu (funkcja potęgowa) zawartości wilgoci $\mathrm{w}$ gazie $\mathrm{w}$ badanych ci- 


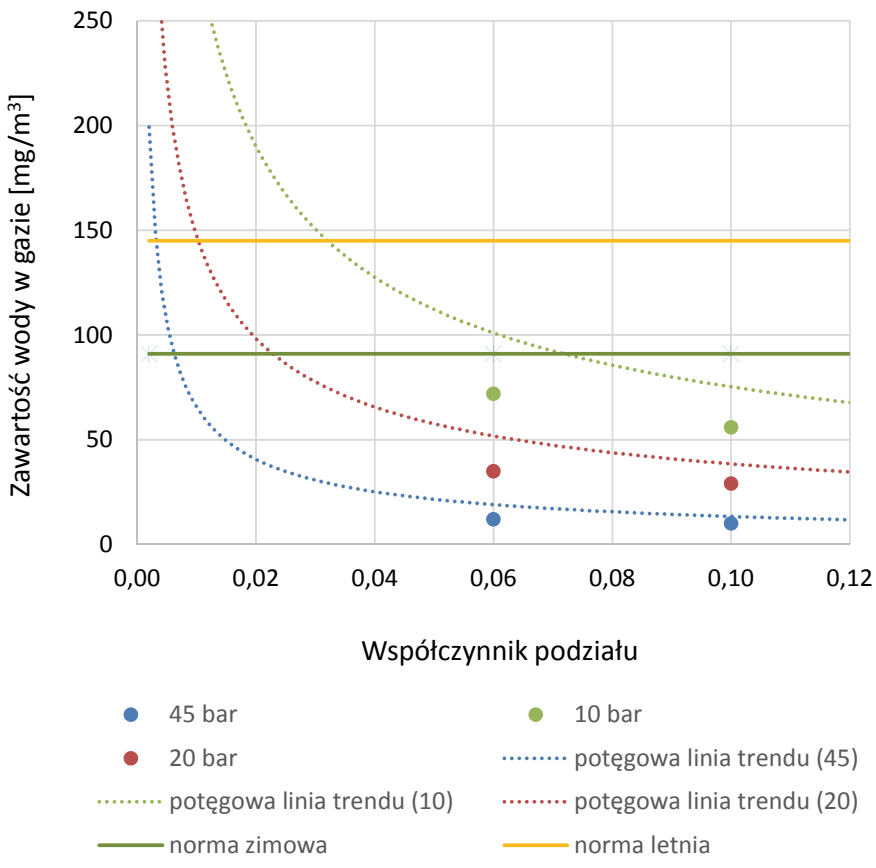

Rys. 9. Symulacja zawartości wilgoci w strumieniu metanu po kontakcie z membraną $\mathrm{w}$ zależności od współczynnika podziału przy ciśnieniach: 10, 20 i 45 bar w temperaturze $18,5^{\circ} \mathrm{C}$

śnieniach, które dążą do wartości stanu nasycenia wodą przy współczynniku podziału dążącym do wartości „0”. Jak widać, linie interpolacyjne są przeszacowane w stosunku do uzyskanych wartości pomiarowych w testach, co pozwala na uniknięcie ryzyka wyciągania zbyt optymistycznych wniosków. Liniami ciągłymi zaznaczono najwyższe dopuszczalne zawartości wody w gazie w zimie (linia zielona) i w lecie (linia ciemnożółta). Jak wynika z takiej interpolacji, aby uzyskać wartości zawilgocenia gazu według normy zimowej, „straty” metanu wysokociśnieniowego wynoszą około 3\% dla 20 bar i poniżej 1\% dla 45 bar. W przypadku wyższych ciśnień należy się spodziewać otrzymania odpowiedniego stopnia osuszenia w zimie także przy wartościach współczynnika podziału poniżej 0,01 (udziału strumienia permeatu (,straty”) w strumieniu wlotowym poniżej 1\%).

W okresie letnim zapewnienie osuszania odpowiadającego normom przy ciśnieniach gazu powyżej 45 bar może być osiągnięte przy strumieniu permeatu nawet poniżej $0,5 \%$ w stosunku do ilości gazu wlotowego. Należy jednocześnie zaznaczyć, że zawilgocony gaz niskociśnieniowy można zagospodarować na lokalne potrzeby.

W przypadku dużych przepływów i gdy jednocześnie nie ma zapotrzebowania lokalnego na gaz niskociśnieniowy, można zaprojektować proces w taki sposób, aby $100 \%$ gazu wlotowego znajdowało się w wysokociśnieniowym strumieniu gazu po osuszeniu na membranach. W tym celu strumień permeatu należy zawrócić po sprężeniu, wychłodzeniu i oddzieleniu wykroplonej wody do strumienia gazu wlotowego. Takie rozwiązanie przedstawiono na rysunku 10.

Na rysunku 10 przedstawiono także inne warianty rozwiązań technologicznych osuszania gazu na membranach. Strumień permeatu (11) może być podzielony na strumień (12) do zagospodarowania lokalnego i strumień (13) do recyrkulacji poprzez sprężarkę, jako strumień (15) dołączony do strumienia wlotowego (1). W sytuacji, gdyby ciśnienie gazu wlotowego obniżyło się do poziomu poniżej 10 bar, co mogłoby powodować niewystarczający poziom jego osuszania, można podnieść jego ciśnienie na sprężarce, a $\mathrm{z}$ zawodnionego strumienia (2) wykroplić wodę w oddzielaczu, która może się pojawić po tej operacji.

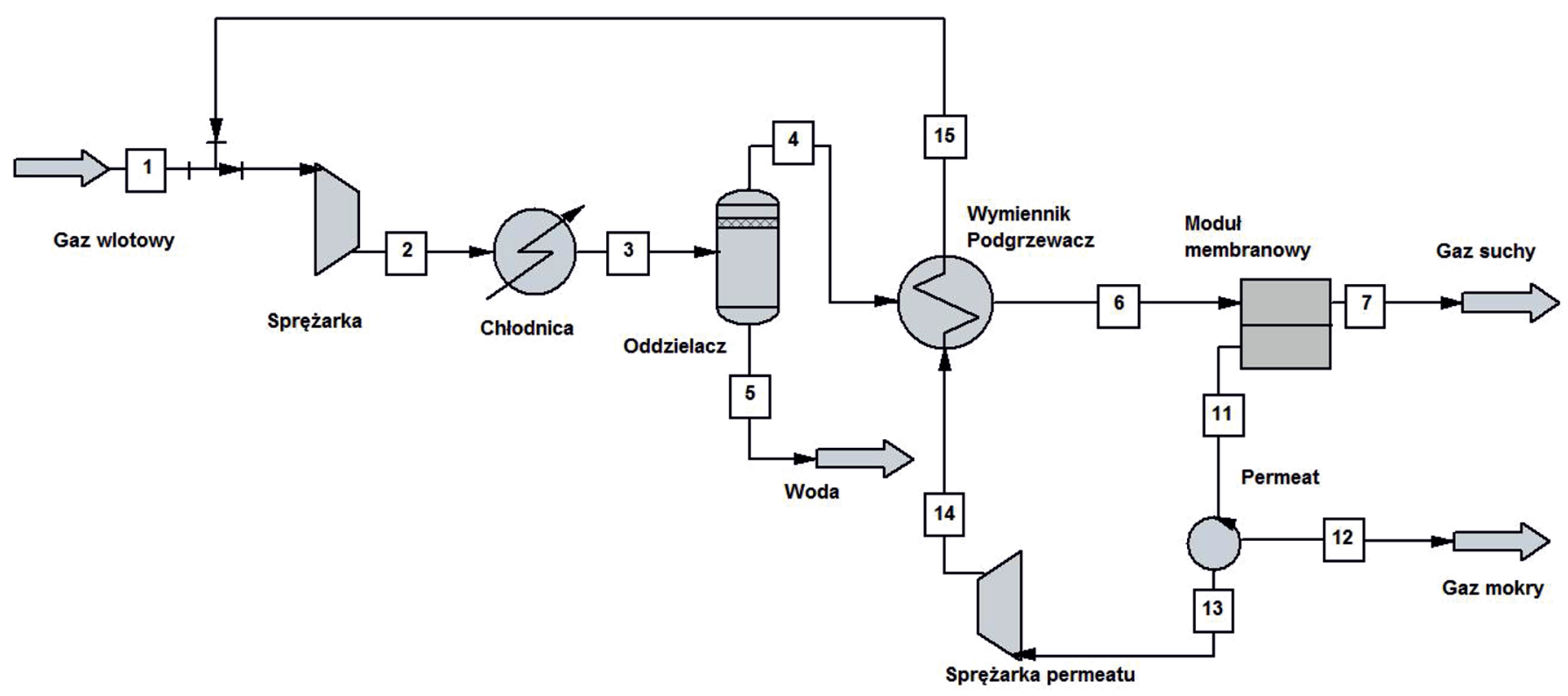

Rys. 10. Schemat wielowariantowych rozwiązań technologicznych osuszania gazu na membranach 


\section{Podsumowanie}

$\mathrm{Na}$ laboratoryjnej instalacji z modułem membranowym umożliwiającej pomiary temperatury, ciśnienia i wilgotności strumieni gazów przeprowadzono badania osuszania azotu, metanu i gazu ziemnego, uzyskując wysokie stopnie obniżenia wilgotności tych gazów. Badania prowadzono na mikrokapilarnych membranach (hollow fiber) wykonanych z poliimidu o strukturze zwarto-porowatej. Stwierdzono, że efektywność osuszania gazu po kontakcie z membraną zależy od wartości przepływów, od ciśnienia i temperatury. Wraz ze wzrostem ciśnienia transmembranowego efektywność od- wodnienia się zwiększa. Przy ciśnieniu gazu powyżej 10 bar uzyskiwany jest poziom zawilgocenia odpowiadający wymaganiom normy osuszania gazu w zimie, przy współczynniku podziału powyżej 0,08. Przy ciśnieniu gazu powyżej 45 bar norma osuszania spełniona jest przy współczynniku podziału poniżej 0,01 (strumień niskociśnieniowego gazu nie przekracza 1\% strumienia wlotowego).

Jeśli nie ma możliwości lokalnego zagospodarowania niskociśnieniowego strumienia gazu, można zastosować częściową cyrkulację i doprężenie permeatu.

Prosimy cytować jako: Nafta-Gaz 2017, nr 7, s. 502-509, DOI: 10.18668/NG.2017.07.08

Artykuł nadesłano do Redakcji 9.12.2016 r. Zatwierdzono do druku 24.05.2017 r.

Artykuł powstał na podstawie pracy statutowej pt. Określenie możliwości odwadniania gazu ziemnego na membranach polimerowych - praca INiG - PIB na zlecenie MNiSW; nr zlecenia 0035/KE, nr archiwalny KE-4101-0035/16.

\section{Literatura}

[1] Baker R.W., Lokhandwala K.: Natural gas processing with membranes: an overview. Ind. Eng. Chem. Res. 2008, vol. 47, s. 2109-2121.

[2] Bernardo P., Clarizia G.: 30 Years of membrane technology for gas separation. Chemical Engineering Transactions 2013, vol. 32, s. 1999-2004.

[3] Bukacek R.F.: Equilibrium Moisture Content of Natural Gases. Research Bulletin 8, Institute of Gas Technology, Pipeline Research Committee of the American Gas Association 1955.

[4] Chen G.Q., Scholes C.A., Qiao G.G., Kentish S.E.: Water vapor permeation in polyimide membranes. Journal of Membrane Science 2011, vol. 379, nr 1-2, s. 479-487.

[5] Holewa J., Szlęk M.: Ocena jakości gazów palnych. NaftaGaz 2013, nr 6, s. 450-454.

[6] Huang J., Cranford R.J., Matsuura T., Roy C.: Water vapor sorption and transport in dense polyimide membranes. Journal of Applied Polymer Science 2003, vol. 87, nr 14, s. 2306-2317.

[7] Janocha A.: Badania obniżania zawartości $\mathrm{CO}_{2} w$ gazie ziemnym przy użyciu membrany poliimidowej. Nafta-Gaz 2016, nr 3, s. 186-191, DOI: 10.18668/NG.2016.03.05.

[8] Lin H., Thompson S.M., Serbanescu-Martin A., Wijmans J.G., Amo K.D., Lokhandwala K.A., Merkel T.C.: Dehydration of natural gas using membranes. Part I: Composite membranes. Journal of Membrane Science 2012, vol. 413-414, s. 70-81.

[9] Lin H., Thompson S.M., Serbanescu-Martin A., Wijmans J.G., Amo K.D., Lokhandwala K.A., Ting Low B., Merkel T.C.: Dehydration of natural gas using membranes. Part II: Sweep/ countercurrent design and field test. Journal of Membrane Science 2013, vol. 432, s. 106-114.

[10] Lin H., White L.S., Lokhandwala K., Baker R.W.: Natural Gas Purification. Encyclopedia of Membrane Science and Technology. John Wiley \& Sons, Inc. 2013.

[11] Lin Z., Junming F., Jia Z., Li O., Luling L.: Formula calculation methods of water content in sweet natural gas and their adaptability analysis. Natural Gas Industry B 2014, vol. 1, nr 12, s. 144-149.
[12] Masanori Hara, Yuka Togashi: Tritiated water permeation and sorption in polyimide film. Journal of Nuclear Materials 2012, vol. 429, nr 1-3, s. 325.

[13] Metz S., van de Ven W.J.C., Potreck J., Mulder M.H.V., Wessling M.: Transport of water vapor and inert gas mixtures through highly selective and highly permeable polymer membranes. Journal of Membrane Science 2005, vol. 251, s. $29-41$.

[14] Ohlrogge K., Keil B., Wind J.: Dehydration and hydrocarbon dewpointing of natural gas by membrane technology. American Chemical Society 2001, vol. 221, s. U225-U1225.

[15] Scholes C.A., Stevens G.W., Kentish S.E.: Membrane gas separation applications in natural gas processing. Fuel 2012, vol. 96, s. 15-28.

[16] Stookey D.J.: Gas-separation Membrane Applications. [W:] Nunes S.P., Peinemann K.-V. (eds.): Membrane Technology in the Chemical Industry. Edited by Wiley-VCH Verlag $\mathrm{GmbH}$ 2001, s. 43-48.

[17] Szwast M.: Nowe membrany do osuszania gazu ziemnego. Przemysł Chemiczny 2015, nr 12, s. 2213-2217.

[18] UBE - materiały informacyjne udostępnione przez firmę UBE.

[19] Wind J.D., Paul D.R., Koros W.J.: Natural gas permeation in polyimide membranes. Journal of Membrane Science 2004, vol. 228, s. 227-236.

\section{Akty prawne i normatywne}

[20] PN-C-04752:2011 Gaz ziemny. Jakość gazu w sieci przesytowej.

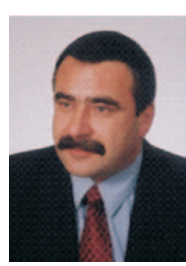

Dr Andrzej JANOCHA

Adiunkt w Zakładzie Technologii Eksploatacji

Płynów Złożowych.

Instytut Nafty i Gazu - Państwowy Instytut Badawczy

ul. Lubicz 25 A

31-503 Kraków

E-mail: andrzej.janocha@inig.pl 